\title{
Physical, Thermal and Spectroscopic Studies on Biofield Treated p-Dichlorobenzene
}

\author{
Mahendra Kumar Trivedi ${ }^{1}$, Alice Branton ${ }^{1}$, Dahryn Trivedi', Gopal Nayak ${ }^{1}$, Ragini Singh ${ }^{2}$ and Snehasis Jana ${ }^{2 *}$
}

${ }^{1}$ Trivedi Global Inc., 10624 S Eastern Avenue Suite A-969, Henderson, NV 89052, USA

${ }^{2}$ Trivedi Science Research Laboratory Pvt. Ltd., Hall-A, Chinar Mega Mall, Chinar Fortune City, Hoshangabad Rd., Bhopal- 462026, Madhya Pradesh, India

\begin{abstract}
Para-dichlorobenzene ( $p$-DCB) is widely used as a chemical intermediate in manufacturing of dyes, pharmaceuticals, polymers and other organic synthesis. The aim of present study was to evaluate the impact of biofield treatment on physical, thermal, and spectroscopic properties of $p$-dichlorobenzene. The $p$-dichlorobenzene sample was divided into two groups that served as treated and control. The treated group received Mr. Trivedi's biofield treatment. Subsequently the control and treated samples were evaluated using X-ray diffraction (XRD), differential scanning calorimetry (DSC), thermogravimetric analysis (TGA) and UV-Vis spectroscopy. XRD result showed an increase in crystallite size $(4.93 \%)$ along with alteration in peak intensity of treated sample as compared to control. Furthermore, DSC analysis results showed that the latent heat of fusion of treated $p$-dichlorobenzene was considerably reduced by $8.66 \%$ as compared to control. The reduction in melting point of treated sample $\left(54.99^{\circ} \mathrm{C}\right)$ was also observed as compared to control $\left(57.01^{\circ} \mathrm{C}\right)$ $p$-dichlorobenzene. Moreover, TGA/DTG studies showed that $\mathrm{T}_{\text {max }}$ (temperature, at which sample lost maximum of its weight) was increased by $6.26 \%$ and weight loss per degree celsius $\left({ }^{\circ} \mathrm{C}\right.$ ) was decreased by $12.77 \%$ in biofield treated $p$-dichlorobenzene as compared to control sample. It indicates that thermal stability of treated $p$-dichlorobenzene sample might increase as compared to control sample. However, no change was found in UV-Vis spectroscopic character of treated $p$-dichlorobenzene as compared to control. These findings suggest that biofield treatment has significantly altered the physical and thermal properties of $p$-dichlorobenzene, which could make it more useful as a chemical intermediate.
\end{abstract}

Keywords: Biofield treatment; Para-dichlorobenzene; X-ray diffraction study; Differential scanning calorimetry; Thermogravimetric analysis; and UV-Visible spectroscopy

\section{Introduction}

Chlorobenzenes are the colourless liquid with an almond-like odour. The compound does not occur widely in nature, but it is one of those chemicals which are produced industrially in large amounts. They have many applications, such as intermediate products of the chemical and pharmaceutical industries and as biocides and additives [1]. Chlorination of chlorobenzenes in the presence of variety of catalysts produce ortho and para-Dichlorobenzene isomers. $p$-DCB results from chlorination of chlorobenzene and have wide applications. 1,4-Dichlorobenzene ( $p$-DCB; formula: $\mathrm{C}_{6} \mathrm{H}_{4} \mathrm{Cl}_{2}$ ) is a colourless solid having strong odour. It is mainly used as insecticide and fungicide on crops and air deodorizer [2]. Nowadays, it is used in the production of mothballs in place of naphthalene. Moreover, it is used as chemical intermediate to manufacture dyes, agrochemicals, pharmaceuticals, 2,5-dichloroaniline, plastics, polymers (e.g polyphenylene sulfide resins used for surface coatings and molding resins), and other organic synthesis $[3,4]$. Besides, it is also used in ear preparations as ear wax softener and help in the removal of the wax [5]. To be used as intermediate in various chemical reactions, the rate of reaction of p-DCB plays a crucial role. Carballo et al. reported that rate of reaction in organic compounds can be controlled by modulating the crystallite size [6]. Since $p$-DCB is basically used as chemical intermediate in various reactions, if some changes happened in their crystallite size it may affect the rate of reaction and ultimately the percentage yield. Besides all the benefits associated with $p$-DCB, the low flash point $\left(66^{\circ} \mathrm{C}\right)$ limits its application [7] and this is one of the reasons for the health discomfort of personnel working with them such as headaches, numbness, sleepiness, nausea, and vomiting [8,9]. After considering of $p$-DCB properties, and applications, authors wanted to investigate an economically safe approach that could be beneficial in order to modify the physical, thermal and spectroscopic properties of $p$-DCB. Biofield therapies are very popular in biomedical heath care systems, as well described by National Center for Complementary and Alternative Medicine (NCCAM). NCCAM places biofield therapy in subcategory of energy therapies as one of the five complementary medicine domain [10]. These healing treatment suggest their mechanism upon modulating patient-environmental energy fields. It is scientifically preferred term for the biologically produced electromagnetic and subtle energy field that provides regulatory and communications functions within the organism. The cumulative effect of bio-magnetic and electric field that surrounds the human body is known as biofield energy $[11,12]$. Human has the ability to harness this energy from environment or universe and can transmit the energy into any living or non-living object around this Globe. The object(s) always receive the energy and respond into useful way. This process is termed as biofield treatment. Mr. Trivedi's biofield treatment (The Trivedi Effect ${ }^{\circ}$ ) is well known and significantly studied in different fields such as microbiology [13-15], agriculture [16-18], and biotechnology [19,20]. Recently, the impact of biofield treatment on atomic, crystalline and powder characteristics as well as spectroscopic characters of different materials was studied, and alteration in physical, thermal and chemical properties was reported [21-23]. Hence, based on the outstanding results obtained after biofield treatment on different materials and considering the pharmaceutical applications of $p$-DCB, the present study was undertaken to evaluate

*Corresponding author: Snehasis Jana, Trivedi Science Research Laboratory Pvt. Ltd, Bhopal, Madhya Pradesh, India, Tel: +91-755-6660006; E-mail: publication@trivedisrl.com

Received: July 16, 2015; Accepted: August 21, 2015; Published August 24, 2015

Citation: Trivedi MK, Branton A, Trivedi D, Nayak G, Singh R, et al. (2015) Physical, Thermal and Spectroscopic Studies on Biofield Treated $p$-Dichlorobenzene. Biochem Anal Biochem 4: 204. doi:10.4172/2161-1009.1000204

Copyright: (c) 2015 Trivedi MK, et al. This is an open-access article distributed under the terms of the Creative Commons Attribution License, which permits unrestricted use, distribution, and reproduction in any medium, provided the original author and source are credited. 
the impact of biofield treatment on physical, thermal and spectroscopic characteristics of $p$-DCB.

\section{Materials and Methods}

p-DCB (1,4-dichlorobenzene) was procured from S D Fine Chemicals Pvt., Ltd., India and divided into two parts; one was kept as a control, while other was subjected to Mr. Trivedi's biofield treatment and coded as treated sample. The treatment group in sealed pack was handed over to Mr. Trivedi for biofield treatment under standard laboratory condition. Mr. Trivedi provided the treatment through his energy transmission process to the treated group without touching the sample. The biofield treated sample was returned in the similarly sealed condition for further characterization using XRD, DSC, TGA and UVVis spectroscopic techniques.

\section{X-ray diffraction (XRD) study}

XRD analysis was carried out on Phillips, Holland PW 1710 X-ray diffractometer system, which had a copper anode with nickel filter. The radiation of wavelength used by the XRD system was $1.54056 \AA$. The data obtained were in the form of a chart of $2 \theta$ vs. intensity and a detailed table containing peak intensity counts, $d$ value $(\AA)$, peak width $\left(\theta^{\circ}\right)$, relative intensity $(\%)$ etc.

The crystallite size $(G)$ was calculated by using formula:

$$
\mathrm{G}=\mathrm{k} \lambda /(\mathrm{b} \operatorname{Cos} \theta)
$$

Here, $\lambda$ is the wavelength of radiation used, $b$ is full width half maximum (FWHM) of peaks and $\mathrm{k}$ is the equipment constant $(=0.94)$. However, percent change in crystallite size was calculated using the following equation:

Percent change in crystallite size $=\left[\left(\mathrm{G}_{\mathrm{t}}-\mathrm{G}_{\mathrm{c}}\right) / \mathrm{G}_{\mathrm{c}}\right] \times 100$

Where, $G_{c}$ and $G_{t}$ are crystallite size of control and treated powder samples respectively.

\section{Differential scanning calorimetry (DSC) study}

For studies related to melting point, Differential Scanning Calorimeter (DSC) of Perkin Elmer/Pyris-1, USA with a heating rate of $10^{\circ} \mathrm{C} / \mathrm{min}$ under air atmosphere and flow rate of $5 \mathrm{ml} / \mathrm{min}$ was used. Melting point and latent heat of fusion were obtained from the DSC curve.

Percent change in melting point was calculated using following equations:

$\%$ change in melting point $=\left[\left(\mathrm{T}_{\text {Treated }}-\mathrm{T}_{\text {Control }}\right) / \mathrm{T}_{\text {Control }}\right] \times 100$

Where, $\mathrm{T}_{\text {Control }}$ and $\mathrm{T}_{\text {Treated }}$ are the melting point of control and treated samples, respectively.

Percent change in latent heat of fusion was calculated using following equations: $\%$
$\times 100$

$\%$ change in latent heat of fusion $=\left[\left(\Delta \mathrm{H}_{\text {Treated }}-\Delta \mathrm{H}_{\text {Control }}\right) / \Delta \mathrm{H}_{\text {Control }}\right]$

Where, $\Delta \mathrm{H}_{\text {Control }}$ and $\Delta \mathrm{H}_{\text {Treated }}$ are the latent heat of fusion of control and treated samples, respectively.

\section{Thermogravimetric analysis/ Derivative Thermogravimetry (TGA/DTG)}

Thermal stability of control and treated samples of $p$-DCB were analyzed by using Metller Toledo simultaneous Thermo-gravimetric analyser (TGA/DTG). The samples were heated from room temperature to $400^{\circ} \mathrm{C}$ with a heating rate of $5^{\circ} \mathrm{C} / \mathrm{min}$ under air atmosphere. From TGA curve, onset temperature $T_{\text {onset }}$ (temperature at which sample start losing weight) and from DTG curve, $\mathrm{T}_{\max }$ (temperature at which sample lost its maximum weight) were recorded.

Percent change in temperature at which maximum weight loss occur in sample was calculated using following equation:

$\%$ change in $\mathrm{T}_{\max }=\left[\left(\mathrm{T}_{\max , \text { treated }}-\mathrm{T}_{\max , \text { control }}\right) / \mathrm{T}_{\max , \text { control }}\right] \times 100$

Where, $\mathrm{T}_{\max \text {, control }}$ and $\mathrm{T}_{\max \text {, treated }}$ are temperature at which maximum weight loss occurs in control and treated sample, respectively.

\section{$\mathrm{UV}-\mathrm{V}$ is spectroscopic analysis}

The UV-Vis spectral analysis was measured using Shimadzu UV2400 PC series spectrophotometer over a wavelength range of 200-400 $\mathrm{nm}$ with $1 \mathrm{~cm}$ quartz cell and a slit width of $2.0 \mathrm{~nm}$. This analysis was performed to evaluate the effect of biofield treatment on structural property of $\mathrm{p}$-DCB. The UV-Vis spectroscopy gives the preliminary information related to the skeleton of chemical structure and possible arrangement of functional groups on the chemical structure [24].

\section{Result and Discussion}

\section{$\mathrm{X}$-ray diffraction}

$\mathrm{X}$-ray diffraction study was conducted to study the crystalline pattern of the control and treated $p$-DCB. Figure 1 showed the XRD diffractogram of control $p$-DCB. It showed intense crystalline peaks at $2 \theta$ equals to $12.96^{\circ}, 26.07^{\circ}, 30.32^{\circ}$, and $39.59^{\circ}$. Intense peaks indicated the crystalline nature of $p$-DCB. Whereas, the XRD diffractogram of treated $p$-DCB showed peaks with less intensity as compared to control sample. The XRD diffractogram of treated $p$-DCB showed (Figure 1) crystalline peaks at $2 \theta$ equals to $12.95^{\circ}, 19.96^{\circ}, 26.09^{\circ}, 26.61^{\circ}$, and $39.59^{\circ}$. It is hypothesized that biofield treatment might disturb the regular arrangement of the molecules, which resulted into less intense peaks in treated $p$-DCB as compared to control. In addition, the crystallite size was found to be 92.647 and $97.213 \mathrm{~nm}$ in control and treated $p-\mathrm{DCB}$, respectively (Figure 2 ). It suggests that crystallite size was increased by $4.93 \%$ in treated $p$-DCB as compared to control
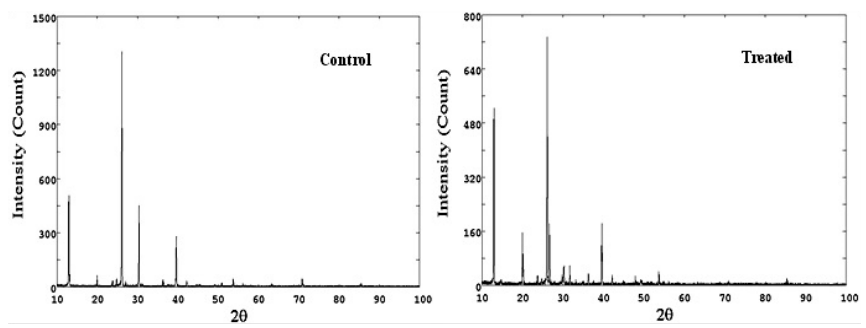

Figure 1: XRD diffractogram of $p$-dichlorobenzene.

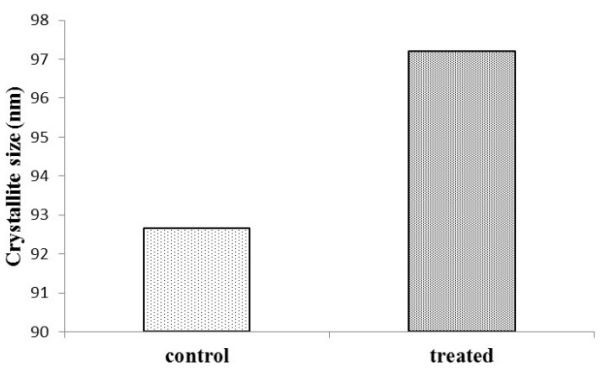

Figure 2: Crystallite size of control and treated sample of $p$-dichlorobenzene. 
It was previously reported that crystallite size increase with elevation in temperature or thermal energy [25-26]. Hence, it is assumed that biofield energy may elevate the temperature or thermal energy which increases the crystallite size of treated $p$-DCB. As $p$-DCB is used as intermediate in the synthesis of many pharmaceutical compounds, the increase in crystallite size may lead to increase in rate of reaction which ultimately enhances the percentage yield of end product.

\section{Thermal Studies}

\section{DSC analysis}

Differential scanning calorimetry (DSC) was used to determine the latent heat of fusion and melting point in control and treated sample of $p$-DCB. The DSC thermogram of control and treated samples of $p$-DCB is shown in Figure 3, and the results are presented in Table 1. In a solid, substantial amount of interaction force exists in atomic bonds to hold the atoms at their positions. Latent heat of fusion $(\Delta \mathrm{H})$ is defined as the energy required overcoming this interaction force to change the phase from solid to liquid. Thus, the energy supplied during phase change i.e. $\Delta \mathrm{H}$ is stored as potential energy of atoms. However, melting point is related to the kinetic energy of the atoms [27]. Data showed that $\Delta \mathrm{H}$ was reduced from $106.62 \mathrm{~J} / \mathrm{g}$ (control) to $97.39 \mathrm{~J} / \mathrm{g}$ in treated $p$-DCB. It indicates that $\Delta \mathrm{H}$ was decreased by $8.66 \%$ in treated sample as compared to control. However, the melting point of treated $p$-DCB was also reduced from $57.01^{\circ} \mathrm{C}$ (control) to $54.99^{\circ} \mathrm{C}$. Thus, data suggest that melting point was reduced by $3.63 \%$ as compared to control (Figure 4). Previously, our group reported that biofield treatment has altered the latent heat of fusion and melting point in lead and tin powder [28]. Thus, it is assumed that biofield treatment might induce the alteration in potential and kinetic energy of p-DCB molecules that possibly resulted into lower the $\Delta \mathrm{H}$ and melting point in treated sample. In addition, the sharpness of the endothermic peaks showed a good degree of crystallinity in control and treated $p$-DCB.
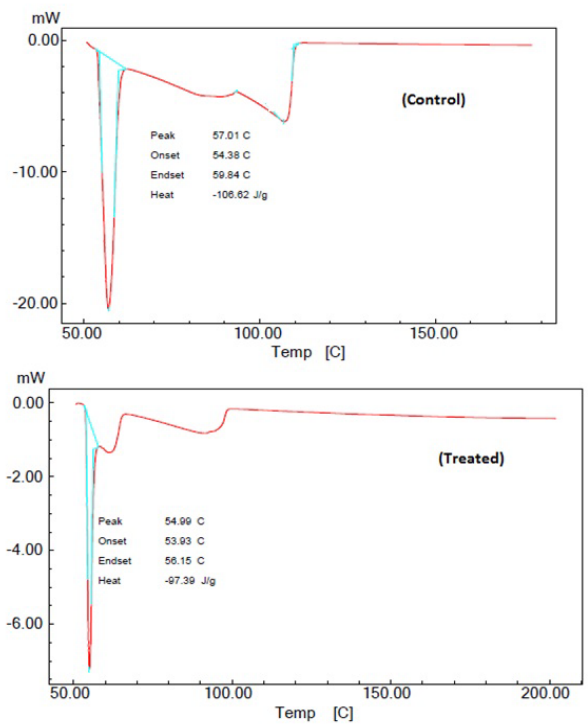

Figure 3: DSC thermogram of control and treated sample of $p$-dichlorobenzene.

\begin{tabular}{|c|c|c|}
\hline Group & $\mathbf{\Delta} \mathbf{H}(\mathbf{J} / \mathbf{g})$ & $\mathbf{T}_{\mathbf{m}}\left({ }^{\circ} \mathbf{C}\right)$ \\
\hline Control & 106.62 & 57.01 \\
\hline Treated & 97.39 & 54.99 \\
\hline
\end{tabular}

$\Delta \mathrm{H}=$ Latent heat of fusion; $\mathrm{T}_{\mathrm{m}}=$ Melting temperature.

Table 1: DSC analysis of control and treated samples of $p$-dichlorobenzene.

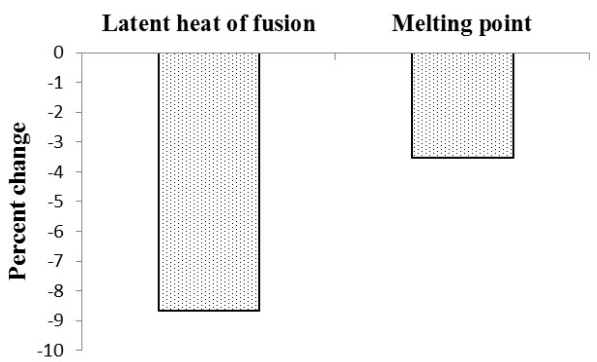

Figure 4: Percent change in latent heat of fusion and melting point in biofield treated pdichlorobenzene sample with respect to control.

\begin{tabular}{|c|c|c|}
\hline Parameters & Control & Treated \\
\hline $\mathrm{T}_{\max }\left({ }^{\circ} \mathrm{C}\right)$ & 94.5 & 100.42 \\
\hline Weight loss $(\mathrm{mg}) /{ }^{\circ} \mathrm{C}$ & 29.69 & 25.9 \\
\hline Weight loss $(\%)$ & 42.16 & 60.29 \\
\hline
\end{tabular}

$T_{\text {max }}$ : temperature at which maximum weight loss occur; TGA/DTG: Thermogravimetric/derivative thermogravimetry

Table 2: Thermal decomposition (TGA/DTG) analysis of control and treated samples of $p$-dichlorobenzene

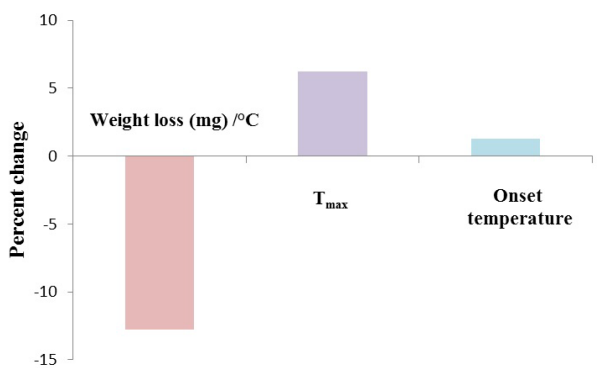

Figure 5: weight loss per degree celsius $\left({ }^{\circ} \mathrm{C}\right)$ in treated $p$-DCB.

\section{TGA/DTG analysis}

Thermal Gravimetric Analysis/Derivative Thermogravimetry analysis (TGA/DTG) of control and biofield treated samples are summarized in Table 2. TGA data showed that control p-DCB sample started losing weight around $79^{\circ} \mathrm{C}$ (onset) and stopped at $115.76^{\circ} \mathrm{C}$ (end set). However, the treated p-DCB started losing weight near to $80^{\circ} \mathrm{C}$ (onset) and terminated at $127^{\circ} \mathrm{C}$ (end set). It indicates that no significant change was found in onset temperature of treated $p$-DCB as compared to control, but end set temperature was increased by $11.24^{\circ} \mathrm{C}$ as compared to control. Furthermore, in this process, control sample lost $42.16 \%$ and treated $p$-DCB sample lost $60.29 \%$ of its weight, which could be due to vaporization of $p$-DCB into its gaseous form. Besides, DTG thermogram data showed that Tmax was found at $94.5^{\circ} \mathrm{C}$ in control whereas, it was increased to $100^{\circ} \mathrm{C}$ in treated $p$-DCB (Table 2). It indicates that Tmax was increased by $6.26 \%$ in treated $p$-DCB. DTG data showed that control sample lost its weight at $29.69 \mathrm{mg} /{ }^{\circ} \mathrm{C}$ during vaporization, whereas treated samples lost its weight at 25.90 $\mathrm{mg} /{ }^{\circ} \mathrm{C}$. It shows that the weight loss per degree celsius $\left({ }^{\circ} \mathrm{C}\right)$ in treated p-DCB was decreased by $12.77 \%$, as compared to control (Figure 5). Furthermore, the reduction in weight loss per ${ }^{\circ} \mathrm{C}$ and increase in Tmax in treated $p$-DCB may be correlated with increase in thermal stability of treated $p$-DCB sample after biofield treatment which might reduce the problem of health hazards related with it. Hence, it is hypothesised that biofield treatment might enhance the intermolecular interaction in $p$-DCB, which probably resulted into the increase of $\mathrm{T}_{\max }$ and reduction 

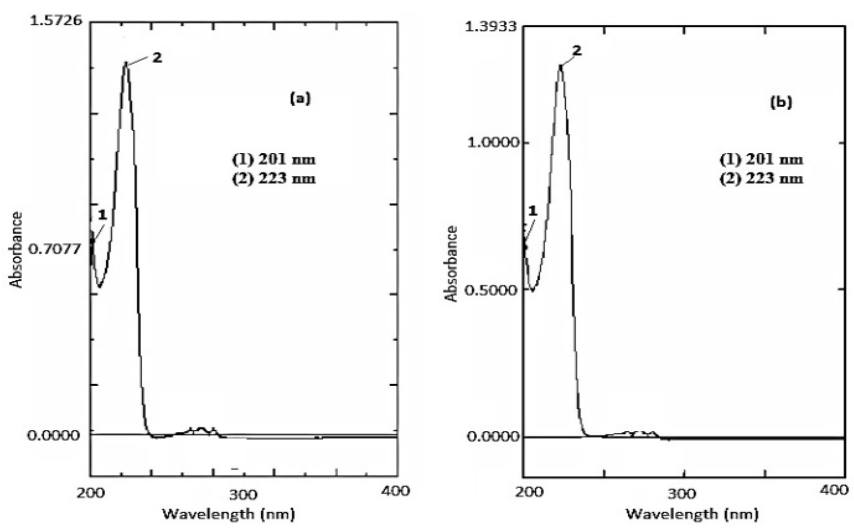

Figure 6: UV spectra of p-dichlorobenzene (a) control and (b) treated.

in weight loss per $^{\circ} \mathrm{C}$.

\section{UV-Vis spectroscopic analysis}

The UV spectra of control and treated sample of $p$-DCB are shown in Figure 6. The UV spectrum of control sample showed two absorption peaks i.e. at 201 and $223 \mathrm{~nm}$, and the spectrum was well supported by literature data [29]. The UV spectrum of treated sample of $p$-DCB also showed similar absorption peaks as compared to control. It suggests that biofield treatment could not make any alteration in the structure of chromophore groups present in $p$-DCB which are mainly responsible for absorption of light.

\section{Conclusion}

This work was evaluated to see the influence of biofield treatment on physical, thermal, and spectroscopic properties of $p$-DCB. XRD result showed that crystallite size was increased by $4.93 \%$ in biofield treated $p$-DCB as compared to control, which might be due to decreasing nucleus densities caused by biofield treatment. The alteration in crystallite size might affect the rate of chemical reaction of $p-\mathrm{DCB}$ and make it more useful as an intermediate compound. Thermal analysis data revealed that latent heat of fusion was reduced by $8.66 \%$ in treated $p$-DCB as compared to control and melting point was reduced by $3.54 \%$. TGA/DTG studies showed that $\mathrm{T}_{\max }$ was increased by $6.26 \%$ and weight loss per degree celsius $\left({ }^{\circ} \mathrm{C}\right)$ was decreased by $12.77 \%$ in biofield treated $p$-DCB as compared to control sample. Hence, it was hypothesized that overall thermal stability of treated $p$-DCB sample increased which could be related to its stability at high temperature and reducing the risk of health hazards associated with products released after vaporization. Therefore, it is assumed that biofield treatment might alter the physical and thermal properties of $p$-DCB that may be helpful to use it more effectively as an intermediate in the production of various pharmaceutical products.

\section{Acknowledgement}

The authors would like to acknowledge the whole team of Sophisticated Analytical Instrument Facility (SAIF), Nagpur, Maharashtra and MGV Pharmacy College, Nashik for providing the instrumental facility. We are very grateful for the support of Trivedi Science, Trivedi Master Wellness and Trivedi Testimonials in this research work.

\section{References}

1. Popp P, Bruggemann L, Keil P, Thuss U, Weiss $H$ (2000) Chlorobenzenes and hexachlorocyclohexanes ( $\mathrm{HCHs}$ ) in the atmosphere of Bitterfeld and Leipzig (Germany). Chemosphere 41: 849-855.

2. Acton QA (2013) Chlorobenzenes-Advances in Research and Application ScholarlyEditions, Atlanta, Georgia.
3. Rossberg M, Lendle W, Pfleiderer G, Togel A, Dreher EL, et al. (2006) Chlorinated hydrocarbons. Ullmann's Encyclopedia of Industrial Chemistry (7thedn) Wiley-VCH, Verlag, Germany.

4. Fahey DR, Ash CE (1991) Mechanism of poly(p-phenylene sulfide) growth from pdichlorobenzene and sodium sulphide. Macromolecules 24: 4242-4249.

5. Katiyar VMH, Prasanna V, Dhanapal E (2014) Comparative study of ceruminolytic effect of distilled water and $2 \%$ para dichlorobenzene. Int J Med Sci Public Health 3: 696-699.

6. Carballo LM, Wolf EE (1978) Crystallite size effects during the catalytic oxidation of propylene on Pt/Y-Al2O3. J Catal 53: 366-373.

7. Mackinson FW, Stricoff RS, Partridge LJ, Little AD (1981) Occupational Health Guidelines for Chemical Hazards. DHHS (NIOSH) Publication No. 81-123, Washington, DC, U.S.

8. Djohan D, Yu J, Connell D, Christensen E (2007) Health risk assessment of chlorobenzenes in the air of residential houses using probabilistic techniques. J Toxicol Environ Health A 70: 1594-1603.

9. Ogata M, Taguchi T, Hirota N, Shimada Y, Nakae S (1991) Quantitation of urinary chlorobenzene metabolites by HPLC: Concentrations of 4-chlorocatechol and chlorophenols in urine and of chlorobenzene in biological specimens of subjects exposed to chlorobenzene. Int Arch Occup Environ Health 63: 121-128.

10. NIH (2008) National Center for Complementary and Alternative Medicine. CAM Basics. Publication 347.

11. Rae A (2006) Quantum Physics: A beginner's guide. One world publications.

12. Thomas AH (2012) Hidden in plain sight: The simple link between relativity and quantum mechanics. Swansea, UK.

13. Trivedi MK, Bhardwaj Y, Patil S, Shettigar H, Bulbule A (2009) Impact of an external energy on Enterococcus faecalis [ATCC-51299] in relation to antibiotic susceptibility and biochemical reactions-an experimental study. J Accord Integr Med 5: 119-130.

14. Trivedi MK, Patil S (2008) Impact of an external energy on Staphylococcus epidermis [ATCC-13518] in relation to antibiotic susceptibility and biochemical reactions-an experimental study. J Accord Integr Med 4: 230-235.

15. Trivedi MK, Patil S (2008) Impact of an external energy on Yersinia enterocolitica [ATCC-23715] in relation to antibiotic susceptibility and biochemical reactions: An experimental study. Internet J Alternat Med 6: 13.

16. Shinde V, Sances F, Patil S, Spence A (2012) Impact of biofield treatment on growth and yield of lettuce and tomato. Aust J Basis Appl Sci 6: 100-105.

17. Sances F, Flora E, Patil S, Spence A, Shinde V (2013) Impact of biofield treatment on ginseng and organic blueberry yield. Agrivita J Agric Sci 35: 22-29.

18. Lenssen AW (2013) Biofield and fungicide seed treatment influences on soybean productivity, seed quality and weed community. Agricultural Journal 8: 138-143.

19. Altekar N, Nayak G (2015) Effect of biofield treatment on plant growth and adaptation. J Environ Health Sci 1: 1-9.

20. Patil SA, Nayak GB, Barve SS, Tembe RP, Khan RR (2012) Impact of biofield treatment on growth and anatomical characteristics of Pogostemon cablin (Benth.). Biotechnology 11: 154-162.

21. Trivedi MK, Tallapragada RR (2008) A transcendental to changing meta powder characteristics. Met Powder Rep 63: 22-28.

22. Dabhade VV, Tallapragada RR, Trivedi MK (2009) Effect of external energy on atomic, crystalline and powder characteristics of antimony and bismuth powders. Bull Mater Sci 32: 471-479.

23. Trivedi MK, Nayak G, Patil S, Tallapragada RM, Latiyal O (2015) Studies of the atomic and crystalline characteristics of ceramic oxide nano powders after bio field treatment. Ind Eng Manage 4: 161.

24. Pavia DL, Lampman GM, Kriz GS (2001) Introduction to spectroscopy. (3rd edn), Thomson learning, Singapore.

25. Rashidi AM, Amadeh A (2009) The effect of saccharin addition and bath temperature on the grain size of nanocrystalline nickel coatings. Surf Coat Technol 204: 353-358.

26. Gusain D, Srivastava V, Singh VK, Sharma YC (2014) Crystallite size and phase transition demeanor of ceramic steel. Mater Chem Phys 145: 320-326. 
Citation: Trivedi MK, Branton A, Trivedi D, Nayak G, Singh R, et al. (2015) Physical, Thermal and Spectroscopic Studies on Biofield Treated p-Dichlorobenzene. Biochem Anal Biochem 4: 204. doi:10.4172/2161-1009.1000204

Page 5 of 5

27. Moore J (2010) Chemistry: The molecular science (4th edn) Brooks Cole.

28. Trivedi MK, Patil S, Tallapragada RM (2013) Effect of biofield treatment on the physical and thermal characteristics of silicon, tin and lead powders. J Material
Sci Eng 2: 125.

29. Hellmann M, Bilbo AJ (1953) The preparation of two fluorinated p-dihalobenzenes. J Am Chem Soc 75: 4590. 